\title{
Relationship between the First Ovulation within Three Weeks Postpartum and Subsequent Ovarian Cycles and Fertility in High Producing Dairy Cows
}

\author{
Chiho KAWASHIMA ${ }^{1)}$, Etsushi KANEKO ${ }^{1)}$, Carlos AMAYA MONTOYA ${ }^{2)}$, \\ Motozumi MATSUI'), Norio YAMAGISHI ${ }^{3) \#}$, Nobuyoshi MATSUNAGA ${ }^{4}$, \\ Mitsuo ISHII ${ }^{3)}$, Katsuya KIDA ${ }^{5)}$, Yoh-Ichi MIYAKE') and Akio MIYAMOTO') \\ ${ }^{1)}$ Graduate School of Animal and Food Hygiene, ${ }^{2)}$ Department of Clinical Veterinary Science, \\ ${ }^{3)}$ Research Center for Animal Hygiene and Food Safety, ${ }^{4)}$ Department of Agricultural and Life \\ Science, ${ }^{5)}$ Field Center of Animal Science and Agriculture, Obihiro University of Agriculture \\ and Veterinary Medicine, Obihiro 080-8555, Japan \\ \#Present address: Research Unit for Diagnosis and Treatment of Food Animal Diseases, \\ Department of Veterinary Clinical Medicine, Faculty of Agriculture, Iwate University, Iwate \\ 020-8550, Japan
}

\begin{abstract}
The aim of this study was to investigate the relationship between the first ovulation within 3 weeks postpartum and subsequent ovarian cycles and fertility in high producing dairy cattle in Hokkaido, Japan. In Experiment 1, 110 cows (44 primiparous and 66 multiparous) were used to determine the effects of the first ovulation within 3 weeks postpartum on subsequent ovarian cycles. Milk samples were collected twice weekly from 7 to 100 days postpartum. The first ovulation was identified by an increase in milk progesterone (P4) to more than $1 \mathrm{ng} / \mathrm{ml}$ within 3 weeks postpartum. The numbers of cows showing ovulation and anovulation within 3 weeks postpartum were 31 (70.5\%) and $13(29.5 \%)$ in the primiparous cows and $35(53.0 \%)$ and $31(47.0 \%)$ in the multiparous cows, respectively. The patterns of ovarian resumption after calving were classified into two types (normal ovarian cycles and abnormal ovarian cycles) on the basis of milk P4 concentrations. Initiation of normal ovarian function in cows ovulated within 3 weeks postpartum occurred earlier than in anovulated cows regardless of the number of calvings (primiparous, 27.8 days vs. 44.4 days; multiparous, 30.6 days vs. 55.7 days; $\mathrm{P}<0.01$ ). Out of the multiparous cows that ovulated within 3 weeks postpartum, initiation of normal ovarian function followed by a normal luteal phase was earlier than when it was followed by an abnormal luteal phase ( 25.5 days vs. 40.4 days; $\mathrm{P}<0.05)$. Milk $\mathrm{P} 4$ concentrations after the first ovulation were lower than those after the second ovulation in both the primiparous and multiparous cows $(\mathrm{P}<0.05)$. In Experiment 2, 22 multiparous cows were used to determine the effects of the first ovulation within 3 weeks postpartum on subsequent fertility. Blood samples were collected once a week from 0 to 3 weeks postpartum. The interval from parturition to first service in ovulated cows was shorter than in anovulated cows (68.4 days vs. 94.8 days; $\mathrm{P}<0.05$ ). The conception rate by 100 days after calving tended to be higher in ovulated cows than in anovulated cows $(50.0 \%$ vs. $16.7 \%, \mathrm{P}=0.09)$. In conclusion, our data strongly suggests that ovulation within 3 weeks postpartum is a crucial phenomenon for subsequent resumption of ovarian function and conception, and thus it can be used as an index of subsequent reproductive performance.

Key words: Dairy cow, First ovulation, Postpartum, Resumption of ovarian cycle
\end{abstract}

(J. Reprod. Dev. 52: 479-486, 2006) 
D uring the last few decades, milk production per cow has drastically increased due to improvement in management, nutrition, and genetic selection [1, 2], but the reproductive performance of dairy cows has conversely declined [1-4]. Several studies suggest that the negative effects of milk production on reproductive function can only be observed in high producing dairy cattle $[2,4-7]$. One of the main reasons for this declining reproductive performance is a lower rate of increase in feed intake compared to the energy necessary for milk production. Namely, cows experience a serious period of negative energy balance during early lactation that is characterized by loss of body weight and mobilization of body fat stores $[7,8]$.

The resumption of ovarian activity plays a crucial role in subsequent fertility [9-11]. Recent studies have shown that the interval from calving to the first ovulation has become longer in high producing dairy cows $[1,4]$, and this can be explained in part by a larger negative energy balance [1, 8]. In most dairy cows, medium-sized follicles appear within 5 days after calving and large follicles appear within 10 days postpartum $[12,13]$. Approximately half of all cows ovulate within 3 weeks postpartum $[9,10,14]$, but in the other half, the dominant follicle of the first follicular wave regresses and the first ovulation occurs about 4 follicular waves later after calving $[15,16]$. This difference in timing of the first ovulation is attributed to suppression of the lutenizing hormone ( $\mathrm{LH})$ pulse frequency by a negative energy balance during this period [7, 17]. Therefore, cows with only a slight negative energy balance may show a shorter interval from calving to first ovulation than those with a severe one.

It is now accepted that if uterine involution is achieved after calving, early resumption of ovarian cycles is directly related to higher fertility $[9,18$, 19]. On the other hand, other studies have demonstrated that early ovulation before 3 weeks postpartum is associated with reduced pregnancy rates and a prolonged calving to conception interval in multiparous dairy cows [20], suggesting that early luteal activity may have a negative impact on involution of the uterus after calving [21, 22]. Thus, it is still controversial whether early resumption of ovarian cycles improves the fertility of dairy cows.

The aim of our study therefore was to investigate the relationship between the first ovulation within 3 weeks postpartum and subsequent ovarian cycles and fertility in high producing dairy cattle in Hokkaido, Japan.

\section{Materials and Methods}

All experimental procedures complied with the Guide for Care and Use of Agricultural Animals of Obihiro University.

\section{Experiment 1}

Animals: Exp. 1 was carried out at the Field Center of Animal Science and Agriculture, Obihiro University of Agriculture and Veterinary Medicine (Obihiro, Japan), using 110 lactating Holstein cows (44 primiparous and 66 multiparous) that calved between May 2001 and September 2003. The cows were housed in a free-stall barn throughout the year and offered a total mixed ration consisting of grass, corn silage, and concentrate. They also grazed during the period between May and October. Milking was performed twice daily (6:00 and 18:00). The average 305-day milk yield was approximately $8,600 \mathrm{~kg}$, and the first month milk yield was $27.5 \pm 0.7 \mathrm{~kg} /$ day in primiparous cows and $39.2 \pm 0.9 \mathrm{~kg} /$ day in multiparous cows $(\mathrm{P}<0.01)$.

Milk sampling: Milk samples were collected twice weekly (Tuesday and Friday) after milking from day 7 to day 100 postpartum. After centrifugation at $3000 \mathrm{rpm}$ for $45 \mathrm{~min}$ at $4 \mathrm{C}$, the fat layer was removed, and the skim milk samples were kept at $-30 \mathrm{C}$ until analysis for progesterone (P4) concentration.

Definition of ovarian activity after calving: When the $\mathrm{P} 4$ concentration in the skim milk from a cow increased to more than $1 \mathrm{ng} / \mathrm{ml}$, the cow was confirmed as having returned to luteal activity [23]. The first ovulation was identified by luteal activity within 3 weeks after calving (Fig. 1-i). The first day when the P4 concentration in the skim milk from cow increased to more than $1 \mathrm{ng} / \mathrm{ml}$ was regarded as the day of initiation of normal ovarian function (Fig. 1-ii). A normal luteal phase was identified if the P4 concentrations in the skim milk samples retained levels of more than $1 \mathrm{ng} / \mathrm{ml}$ over a 7 -day period (Fig. 1-iii). The patterns of ovarian resumption after calving were classified into two types (normal or abnormal cycle) on the basis of the 


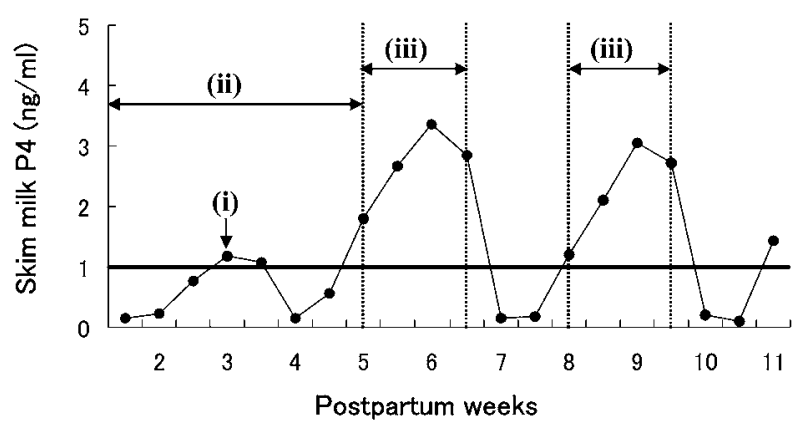

Fig. 1. Ovarian cycles monitored using skim milk progesterone profiling. (i) Ovulation within 3 weeks postpartum, (ii) initiation of normal ovarian function after calving, and (iii) luteal phase.

$\mathrm{P} 4$ profiles in skim milk samples as follows:

Normal cycles: when cows had an ovarian cycle followed by a luteal phase of normal length and this was repeated more than two times.

Abnormal cycles: when cows had an abnormal ovarian cycle, such as a prolonged luteal phase (ovarian cycles after 3 weeks postpartum with a long luteal phase $\geq 22$ days), a short luteal phase (ovarian cycles after 3 weeks postpartum with a short luteal phase $\leq 4$ days), and cessation of cyclicity (no luteal activity for at least 14 days between the first and second luteal phases).

\section{Experiment 2}

Animals: Exp. 2 was carried out using a commercial dairy herd in the Tokachi area of Hokkaido. Twenty-two lactating cows were used. They were housed in a tie-stall throughout the year and offered a total mixed ration consisting of grass silage. The average 305-day milk yield was 10,800 $\mathrm{kg}$.

Reproductive management: The cows calved non-seasonally in both of the herds. Ovaries were scanned once a week by ultrasonography or rectal palpation beginning at 40 days postpartum. If there were apparent reproductive disorders (cystic follicles or anovulation), hormonal treatment using PGF2a and GnRH were applied after 60 days postpartum.

In the Exp. 2 herd, the cows were artificially inseminated at the observed estrus after 50 days postpartum. In addition to internal signs of estrus as detected by rectal palpation, cows with clear vaginal mucous discharge were considered to be in estrus. Conception was confirmed by ultrasonography or rectal palpation 40 and 60 days after each artificial insemination (AI). Cows that did not have a positive pregnancy diagnosis within the period of this study (180 days postpartum) were assumed to have conceived 21 days after their last unsuccessful service [20]. Therefore, this adjusted days open was used as a measure of final fertility.

Blood sampling: Blood samples were obtained by caudal venipuncture once a week between parturition and 3 weeks postpartum using sterile 10 $\mathrm{ml}$ tubes containing $200 \mu \mathrm{l}$ of stabilizer solution $(0.3$ M EDTA, 1\% acetylsalicylic acid, pH 7.4). The tubes were immediately chilled in ice water for 10 min and centrifuged at $3000 \mathrm{rpm}$ for $20 \mathrm{~min}$ at $4 \mathrm{C}$. The plasma samples were kept at $-30 \mathrm{C}$ until analysis for $\mathrm{P} 4$ concentration.

Enzyme immunoassay for P4: Determination of P4 in skim milk and plasma was performed by enzyme immunoassay after extraction by diethyl ether as described previously [24], and the extraction efficiencies for skim milk and plasma were $88 \%$ and $93 \%$, respectively.

\section{Statistical analyses}

Primiparous cows were analyzed separately from multiparous cows to avoid the potentially confounding influence of differences in nutrition and energy balance after parturition on reproductive performance in Exp. 1. The distribution of normal and abnormal ovarian cycles in primiparous and multiparous cows, ovulation within 3 weeks postpartum on repeated parturitions, and conception ratio were examined by chi-square test as an independency test. Other significant differences were analyzed by Student's $t$ test. Results were expressed as means \pm standard error of the mean, with differences of $\mathrm{P}<0.05$ considered significant.

\section{Results}

\section{Experiment 1}

Initiation of normal ovarian function after calving in primiparous cows ( $33.0 \pm 2.6$ days) was earlier than in multiparous cows $(42.6 \pm 2.9$ days, $\mathrm{P}<0.05)$. The numbers of cows with ovulation and anovulation within 3 weeks postpartum were 31 $(70.5 \%)$ and $13(29.5 \%)$ in primiparous cows and 35 $(53.0 \%)$ and $31(47.0 \%)$ in multiparous cows, respectively $(\mathrm{P}=0.07$, Table 1$)$. In spite of ovulation 
Table 1. Number of cows ovulated or anovulated within 3 weeks postpartum and resumption of normal or abnormal ovarian cycles in primiparous and multiparous cows

\begin{tabular}{|c|c|c|c|}
\hline & \multicolumn{2}{|c|}{ Within 3 weeks postpartum } & \multirow{2}{*}{$\begin{array}{l}\text { Significance } \\
\text { of differences }\end{array}$} \\
\hline & Ovulation & Anovulation & \\
\hline \multicolumn{4}{|l|}{ Primiparous cows } \\
\hline Total & 31 & 13 & - \\
\hline Normal cycles followed by repetition of more than two luteal phases & $19(61.3 \%)$ & $7(53.8 \%)$ & \\
\hline Abnormal cycles ${ }^{\dagger}$ & $12(38.7 \%)$ & $6(46.2 \%)$ & ns \\
\hline \multicolumn{4}{|l|}{ Multiparous cows } \\
\hline Total & 35 & 31 & - \\
\hline Normal cycles followed by repetition of more than two luteal phases & $23(65.7 \%)$ & $6(19.4 \%)$ & \\
\hline Abnormal cycles $^{\dagger}$ & $12(34.3 \%)$ & $25(80.6 \%)$ & $* *$ \\
\hline
\end{tabular}

Values are mean \pm SEM.

**P $<0.01 ; \mathrm{ns}$, not significant by chi-square test.

${ }^{+}$Cows having an abnormal cycle, such as a prolonged luteal phase (ovarian cycles after 3 weeks postpartum with a long luteal phase $\geq 22$ days), short luteal phase (ovarian cycles after 3 weeks postpartum with a short luteal phase $\leq 4$ days), or cessation of cyclicity (no luteal activity for at least 14 days between the first and second luteal phases).

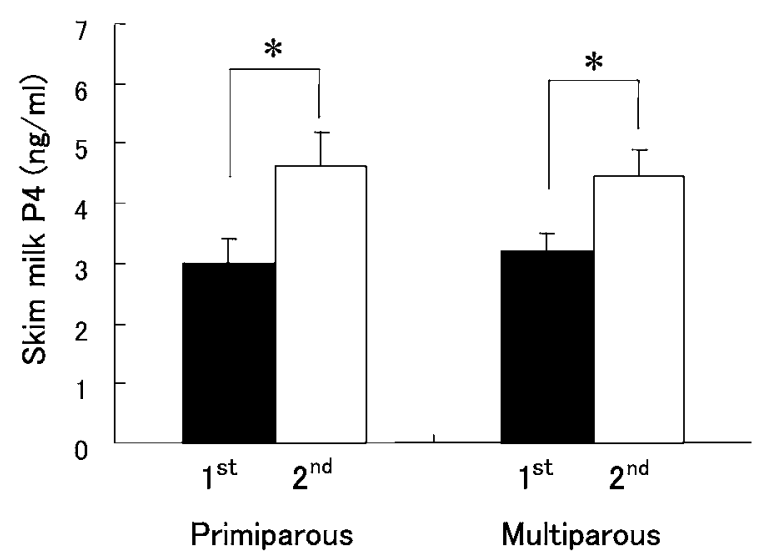

Fig. 2. The highest skim milk progesterone concentrations during the luteal phase after 1st ovulation (i.e, ovulation within 3 weeks postpartum; solid column) and 2 nd ovulation (open column). ${ }^{*} \mathrm{P}<0.05$.

or anovulation within 3 weeks postpartum, 59.1\% of primiparous and $43.9 \%$ of multiparous cows had normal cycles. A few cows with their first ovulation within 3 weeks postpartum had a prolonged luteal phase, indicating a persistent corpus luteum, and the numbers of cows with a persistent corpus luteum in the ovulated and anovulated groups were identical ( $\mathrm{n}=4$ for both).

Characteristics of the luteal phase after ovulation within 3 weeks postpartum: In cows ovulated within 3 weeks postpartum, 16 out of 31 primiparous and 28 out of 35 multiparous cows had a short luteal phase ( $\leq 7$ days) after the first ovulation. Milk P4 concentrations after the first ovulation were lower than those after the second ovulation in both the primiparous and multiparous cows $(\mathrm{P}<0.05$, Fig. 2$)$.

Relationship between the first ovulation within 3 weeks postpartum and subsequent ovarian function: In the multiparous cows, the number of animals with normal cycles followed by repetition of more than two luteal phases was larger in the group with ovulation within 3 weeks postpartum than that in the group without ovulation. On the other hand, the number of animals with abnormal cycles was larger in the group without ovulation than in the group with ovulation $(\mathrm{P}<0.01$, Table 1$)$. Initiation of normal ovarian function in cows ovulated within 3 weeks postpartum was earlier than in anovulated cows despite the number of calvings (16.6 days earlier for the primiparous cows and 25.1 days earlier for the multiparous cows; $\mathrm{P}<0.01$, Table 2). In the primiparous anovulated cows, initiation of normal ovarian function after calving followed by normal cycles was earlier than when followed by abnormal cycles (34.7 days vs. 56.5 days; $\mathrm{P}<0.05$, Table 2), but there was no significant difference in the cows ovulated within 3 weeks postpartum. In the multiparous cows ovulated within 3 weeks postpartum, initiation of normal ovarian function occurred earlier in the cows with normal cycles than in those with abnormal cycles (25.5 days vs. 40.4 days; $\mathrm{P}<0.05$, Table 2).

Ovulation within 3 weeks postpartum for two 
Table 2. Initiation of normal ovarian function in primiparous and multiparous cows showing ovulation or anovulation within 3 weeks postpartum

\begin{tabular}{|c|c|c|c|}
\hline & \multicolumn{2}{|c|}{ Within 3 weeks postpartum } & \multirow{2}{*}{$\begin{array}{l}\text { Significance } \\
\text { of differences }\end{array}$} \\
\hline & Ovulation & Anovulation & \\
\hline \multicolumn{4}{|l|}{ Primiparous cows } \\
\hline Initiation of normal ovarian cycles after calving (days) & $27.8 \pm 2.7(\mathrm{n}=31)$ & $44.4 \pm 4.5(\mathrm{n}=13)$ & $* *$ \\
\hline Normal cycles followed by repetition of more than two luteal phases & $24.6 \pm 2.2(n=19)$ & $34.7 \pm 2.8^{\mathrm{a}}(\mathrm{n}=7)$ & * \\
\hline Abnormal cycles ${ }^{\dagger}$ & $32.3 \pm 5.6(n=12)$ & $56.5 \pm 7.8^{\mathrm{b}}(\mathrm{n}=6)$ & * \\
\hline \multicolumn{4}{|l|}{ Multiparous cows } \\
\hline Initiation of normal ovarian cycles after calving (days) & $30.6 \pm 3.1(n=35)$ & $55.7 \pm 3.8(\mathrm{n}=31)$ & $* *$ \\
\hline Normal cycles followed by repetition of more than two luteal phases & $25.5 \pm 1.6^{\mathrm{x}}(\mathrm{n}=23)$ & $47.2 \pm 8.8(\mathrm{n}=6)$ & $* *$ \\
\hline Abnormal cycles $^{\dagger}$ & $40.4 \pm 7.9^{y}(n=12)$ & $57.2 \pm 4.4(\mathrm{n}=25)$ & ns \\
\hline
\end{tabular}

Values are mean \pm SEM.

${ }^{* *} \mathrm{P}<0.01 ;{ }^{*} \mathrm{P}<0.05 ; \mathrm{ns}$, not significant.

${ }^{\mathrm{a}, \mathrm{b}}$ Indicates differences of $\mathrm{P}<0.05$ within anovulated cows.

$x, y$ Indicates differences of $\mathrm{P}<0.05$ within ovulated cows.

${ }^{\dagger}$ Cows having an abnormal cycle, such as a prolonged luteal phase (ovarian cycles after 3 weeks postpartum with a long luteal phase $\geq 22$ days), short luteal phase (ovarian cycles after 3 weeks postpartum with a short luteal phase $\leq 4$ days), or cessation of cyclicity (no luteal activity for at least 14 days between the first and second luteal phases).

Table 3. Reproductive performance of multiparous cows

\begin{tabular}{lccc}
\hline & \multicolumn{2}{c}{ Within 3 weeks postpartum } & \\
\cline { 2 - 3 } & $\begin{array}{c}\text { Ovulation } \\
(\mathrm{n}=10)\end{array}$ & $\begin{array}{c}\text { Anovulation } \\
(\mathrm{n}=12)\end{array}$ & $\begin{array}{c}\text { Significance } \\
\text { of differences }\end{array}$ \\
\hline Days to first service & $68.4 \pm 8.2$ & $94.8 \pm 7.9$ & $*$ \\
Conception by 100 d postpartum (\%) $_{\text {Conception by 180 d postpartum (\%) }}$ & 50.0 & 16.7 & $\mathrm{P}=0.09$ \\
Adjusted days open $^{1}$ & 71.0 & 58.3 & $\mathrm{~ns}$ \\
\hline
\end{tabular}

Values are mean \pm SEM.

${ }^{*} \mathrm{P}<0.05 ; \mathrm{ns}$, not significant.

${ }^{1}$ Cows that did not have a positive pregnancy diagnosis within the period of this study ( $180 \mathrm{~d}$ postpartum) were assumed to have conceived 21 days after their last unsuccessful service.

consecutive lactation cycles: During the period of this study, 22 cows calved twice. In the two consecutive lactation cycles, 8 out of the 22 cows repeated ovulation within 3 weeks postpartum and 4 of the cows showed signs of anovulation. Consequently, there was no clear statistical tendency found in the distribution of occurrence for ovulation or anovulation within 3 weeks postpartum in the same animals with two consecutive lactation periods after application of the chi-square test.

\section{Experiment 2}

Out of 22 cows examined, 10 cows (45.6\%) ovulated within 3 weeks postpartum. The interval from parturition to first service in the ovulated cows was earlier than in the anovulated cows $(\mathrm{P}<0.05$, Table 3$)$. The 100 -day conception rate after calving in the ovulated cows tended to be higher than in the anovulated cows $(\mathrm{P}=0.09)$. However, there was no significant difference between the 2 groups in the ratio of conception by 180 days after calving. The adjusted days open was longer in the ovulated cows than in the anovulated cows $(\mathrm{P}<0.05$, Table 3).

\section{Discussion}

The present study clearly indicates that initiation of normal ovarian function in both primiparous and multiparous high producing dairy cows ovulated within 3 weeks postpartum is earlier than in anovulated cows. The results further show that this first ovulation relates to the shorter interval from parturition to first service compared with the 
long interval in anovulated cows, and consequently the ratio of conception by 100 days after calving tended to be higher in the ovulated cows.

The ratio of ovulation within 3 weeks postpartum in the primiparous cows tended to be higher than that of the multiparous cows $(71 \%$ vs. $53 \% ; \mathrm{P}=0.07$ ), and $60 \%$ of the cows resumed normal ovarian cycles despite ovulation or anovulation within 3 weeks postpartum. On the other hand, ovulation within 3 weeks postpartum in the multiparous cows induced a high ratio of subsequent ovarian cycles followed by a normal luteal phase repeated more than two times. In the present study, a relatively high proportion of primiparous cows had ovulation within 3 weeks postpartum compared with a previous study, which found the rate to be $53 \%$ [20]. Recent studies indicate that the LH pulse frequency [8] and plasma insulin-like growth factor-1 (IGF-1) level [8, 25] are closely related to the first ovulation during the postpartum period. Negative energy balance, which is caused by insufficient feed intake for milk production, reduces the LH pulse frequency $[8,17]$ and plasma IGF-1 level [26], results in delayed resumption of ovarian activity. The lower milk yield in the first month found in the primiparous cows in the present study may be one of the reasons for the high ratio of ovulation within 3 weeks postpartum and resumption of normal ovarian cycles. In addition, it is believed that the rate of dietary intake of the multiparous anovulated cows was too low for the energy necessary for milk production and that this affected ovulation within 3 weeks postpartum. Undoubtedly, further studies are needed to assess the relationships among milk production, metabolic and reproductive endocrinology, and resumption of ovarian function during the postpartum period.

There is adequate evidence indicating that first ovulation closely relates to earlier resumption of ovarian function, earlier first service, and conception in high producing dairy cows [9, 19]. On the other hand, other researchers have shown in multiparous cows that the ratio of animals having normal ovarian cycles among cows anovulated within 3 weeks postpartum (85\%) was higher than in ovulated cows (68\%) [20]. Our results in high producing dairy cows in Hokkaido confirmed the above results and showed that initiation of normal ovarian function in ovulated cows within 3 weeks postpartum is earlier than that in anovulated cows despite the number of calvings $(\mathrm{P}<0.01)$. In previous studies, it has been shown that earlier resumption of normal ovarian cycles is induced by reducing loss of body weight, increasing dry matter intake [18], and improving body condition score [27]. Therefore, it may be possible to use identification of ovulation within 3 weeks postpartum as an index for evaluation of nutritional status in relation to resumption of normal ovarian function.

In previous studies, it has been shown that the luteal phase after the first ovulation postpartum is abnormal and shorter than normal luteal phases $[28,29]$. Similarly, our data showed that a short luteal phase ( $\leq 7$ days) after the first ovulation within 3 weeks postpartum occurred in a half of the primiparous cows and $80 \%$ of the multiparous cows. In addition, it was also clear that the plasma $\mathrm{P} 4$ concentration after the first ovulation was lower compared to that after the second ovulation despite the number of calvings $(\mathrm{P}<0.05)$. It has been suggested that such a short period of elevated P4 concentrations during the postpartum period induces expression of a normal ovarian cycle [30, 31]. Therefore, the present study indicated that a short luteal phase with low P4 level after the first ovulation was sufficient for resumption of ovarian activity.

It has been shown that the plasma concentration of P4 after early first ovulation increases the occurrence of uterine infection and endometritis [21]. It is also known that endometritis prevents release of luteolytic PGF2a from the uterus [21] and often induces a persistent corpus luteum [32]. Our data showed that the number of cows with a persistent corpus luteum in the ovulated and anovulated groups were identical. Thus, the increase in $\mathrm{P} 4$ concentration after ovulation within 3 weeks postpartum had no negative effect on recovery of the uterus after calving in this herd.

During the period of this study, 22 cows calved twice and one cow showed no significant repeatability in ovulation or anovulation within 3 weeks postpartum over the course of two consecutive lactation cycles. Therefore, it is likely that the occurrence of ovulation or anovulation within 3 weeks postpartum does not depend on genetic factors.

The present results from the herd in Exp. 2 clearly showed that the occurrence of ovulation within 3 weeks postpartum positively affected the 
interval from parturition to first service, the ratio of conception by 100 days after calvings, and the adjusted days open. Resumption of ovarian activity has been shown to play an important role in subsequent fertility in dairy cows $[9,11]$, and abnormal ovarian cycles before service have been shown to have negative effects on reproductive performance, including interval to first $\mathrm{AI}$ and pregnancy rate [33]. In addition, early estrous activity and higher numbers of estrous cycles before service may be indicators of greater restoration of reproductive efficiency [34]. Thus, first ovulation within 3 weeks postpartum is considered to have an impact on the recovery of ovarian function and high fertility, and this well supports the results of a previous study by other researchers [10]. In this context, monitoring of the first ovulation within 3 weeks postpartum using plasma or milk P4 could be used to estimate nutritional and reproductive status after calving and may be useful for management of nutrition and voluntary waiting period.

In conclusion, ovulation within 3 weeks postpartum could be an early index of recovery of normal ovarian function and subsequent reproductive performance in high producing dairy cows. The exact relationship between the occurrence of first ovulation, nutritional status, and fertility should be clarified by large-scale field and experimental studies in Hokkaido.

\section{Acknowledgments}

The authors thank Dr. K. Okuda, Okayama University, Japan, for P4 antiserum. This study was supported by a Grant-in-Aid for Scientific Research from the Japan Society for the Promotion of Science (JSPS) and by the 21st Century COE Program (A-1) of the Ministry of Education, Culture, Sports, Science and Technology of Japan, the Secure and Healthy Livestock Farming Project of the Ministry of Agriculture, Forestry and Fisheries of Japan, and the Japan Livestock Technology Association. C. Kawashima and E. Kaneko were supported by the COE Program.

\section{References}

1. Lucy MC. Reproductive loss in high-producing dairy cattle: where will it end? J Dairy Sci 2001; 84: 1277-1293.

2. Hansen LB. Consequences of selection for milk yield from a geneticist's viewpoint. J Dairy Sci 2000; 83: 1145-1150.

3. Butler WR. Review: effect of protein nutrition on ovarian and uterine physiology in dairy cattle. J Dairy Sci 1998; 81: 2533-2539.

4. Butler WR, Smith RD. Interrelationships between energy balance and postpartum reproductive function in dairy cattle. J Dairy Sci 1989; 72: 767-783.

5. Lamming GE, Darwash AO. The use of milk progesterone profiles to characterise components of subfertility in milked dairy cows. Anim Reprod Sci 1998; 52: 175-190.

6. Lucy MC, Thatcher WW, Collier RJ, Simmen FA, Ko Y, Savio JD, Badinga L. Effects of somatotropin on the conceptus, uterus, and ovary during maternal recognition of pregnancy in cattle. Domest Anim Endocrinol 1995; 12: 73-82.

7. Roche JF, Mackey D, Diskin MD. Reproductive management of postpartum cows. Anim Reprod Sci 2000; 60-61: 703-712.

8. Beam SW, Butler WR. Effects of energy balance on follicular development and first ovulation in postpartum dairy cows. J Reprod Fertil Suppl 1999;
54: 411-424.

9. Darwash AO, Lamming GE, Woolliams JA. The phenotypic association between the interval to postpartum ovulation and traditional measures of fertility in dairy cattle. Anim Sci 1997; 65: 9-16.

10. Lucy MC, Staples CR, Thatcher WW, Erickson PS, Cleale RM, Firkins JL, Clark JH, Murphy MR, Brodie BO. Influence of diet composition, dry matter intake, milk production and fertility in dairy cows. Anim Prod 1992; 54: 323-331.

11. Webb R, Lamming GE, Haynes NB, Hafs HD, Manns JG. Response of cyclic and post-partum suckled cows to injections of synthetic LH-RH. J Reprod Fertil 1977; 50: 203-210.

12. Savio JD, Boland MP, Hynes N, Roche JF. Resumption of follicular activity in the early postpartum period of dairy cows. J Reprod Fertil 1990; 88: 569-579.

13. Savio JD, Boland MP, Roche JF. Development of dominant follicles and length of ovarian cycles in post-partum dairy cows. J Reprod Fertil 1990; 88: 581-591.

14. Lamming GE, Bulman DC. The use of milk progesterone radioimmunoassay in the diagnosis and treatment of subfertility in dairy cows. $\mathrm{Br} \mathrm{Vet} J$ 1976; 132: 507-517.

15. McDougall S, Burke CR, MacMillan KL, 
Williamson NB. Patterns of follicular development during periods of anovulation in pasture-fed dairy cows after calving. Res Vet Sci 1995; 58: 212-216.

16. Sakaguchi M, Sasamoto Y, Suzuki T, Takahashi Y, Yamada Y. Postpartum ovarian follicular dynamics and estrous activity in lactating dairy cows. J Dairy Sci 2004; 87: 2114-2121.

17. Butler WR. Nutritional interactions with reproductive performance in dairy cattle. Anim Reprod Sci 2000; 60-61: 449-457.

18. Staples CR, Thatcher WW, Clark JH. Relationship between ovarian activity and energy status during the early postpartum period of high producing dairy cows. J Dairy Sci 1990; 73: 938-947.

19. Senatore EM, Butler WR, Oltenacu PA. Relationship between energy balance and postpartum ovarian activity and fertility in first lactation dairy cows. Anim Sci 1996; 62: 17-23.

20. Smith MC, Wallace JM. Influence of early post partum ovulation on the re-establishment of pregnancy in multiparous and primiparous dairy cattle. Reprod Fertil Dev 1998; 10: 207-216.

21. Lewis GS. Uterine health and disorders. J Dairy Sci 1997; 80: 984-994.

22. Sheldon IM, Dobson H. Postpartum uterine health in cattle. Anim Reprod Sci 2004; 82-83: 295-306.

23. Stevenson JS, Britt JH. Relationships among luteinizing hormone, estradiol, progesterone, glucocorticoids, milk yield, body weight and postpartum ovarian activity in Holstein cows. $J$ Anim Sci 1979; 48: 570-577.

24. Miyamoto A, Okuda K, Schweigert FJ, Schams D. Effects of basic fibroblast growth factor, transforming growth factor-beta and nerve growth factor on the secretory function of the bovine corpus luteum in vitro. J Endocrinol 1992; 135: 103-114.

25. Beam SW, Butler WR. Energy balance, metabolic hormones, and early postpartum follicular development in dairy cows fed prilled lipid. J Dairy
Sci 1998; 81: 121-131.

26. Spicer LJ, Tucker WB, Adams GD. Insulin-like growth factor-I in dairy cows: relationships among energy balance, body condition, ovarian activity, and estrous behavior. J Dairy Sci 1990; 73: 929-937.

27. Shrestha HK, Nakao T, Higaki T, Suzuki T, Akita M. Resumption of postpartum ovarian cyclicity in high-producing Holstein cows. Theriogenology 2004; 61: 637-649.

28. Bulman DC, Lamming GE. Milk progesterone levels in relation to conception, repeat breeding and factors influencing acyclicity in dairy cows. J Reprod Fertil 1978; 54: 447-458.

29. Horan B, Mee JF, O'Connor P, Rath M, Dillon P. The effect of strain of Holstein-Friesian cow and feeding system on postpartum ovarian function, animal production and conception rate to first service. Theriogenology 2005; 63: 950-971.

30. Webb R, Lamming GE, Haynes NB, Hafs HD, Manns JG. Response of cyclic and post-partum suckled cows to injections of synthetic LH-RH. J Reprod Fertil 1977; 50: 203-210.

31. Rhodes FM, McDougall S, Burke CR, Verkerk GA, Macmillan KL. Invited review: treatment of cows with an extended postpartum anestrous interval. J Dairy Sci 2003; 86: 1876-1894.

32. Ramadan AA, Johnson GL, 3rd, Lewis GS. Regulation of uterine immune function during the estrous cycle and in response to infectious bacteria in sheep. J Anim Sci 1997; 75: 1621-1632.

33. Shrestha HK, Nakao T, Suzuki T, Higaki T, Akita M. Effects of abnormal ovarian cycles during preservice period postpartum on subsequent reproductive performance of high-producing Holstein cows. Theriogenology 2004; 61: 1559-1571.

34. Thatcher WW, Wilcox CJ. Postpartum estrus as an indicator of reproductive status in the dairy cow. J Dairy Sci 1973; 56: 608-610. 